Миланка Ј. Бабић

Универзитет у Источном Сарајеву

Филозофски факултет Пале

Катедра за србистику

rasovaca@yahoo.com

https://doi.org/10.18485/ai_gozik.2019.ch3

821.163.41.09-32

\title{
КОНЦЕПТ ТРАДИЦИОНАЛНЕ ГОЗБЕ У СРПСКОЈ КЊИЖЕВНОСТИ
}

У раду се анализира лексичко-семантички концепт традиционалне гозбе и њена функција у књижевном тексту, на корпусу приповијетке из периода српског реализма или настале у духу реалистичке традиције, будући да се трансформацијом књижевног текста у умјетнички у том књижевном поступку обликује вјерна слика стварности, која је врло блиска појмовно-логичком потенцијалу који природни језик садржи. То омогућује да су аспекти значења концептуално уобличене цјелине, као што је гозба у књижевном тексту, у суштини подударни са неким од рјечничких значења лексема које тај концепт уобличавају, што се у анализи, когнитивно-концептуалног типа, провјерава и у одговарајућим рјечницима српског језика.

Кључне ријечи: концепт, домен, метафора, метонимија, обичај, обред. 


\section{1. УВОДНЕ НАПОМЕНЕ}

У концептуално-когнитивној ${ }^{1}$ анализи гозба је друштвени догађај који је одређен доменом² славља (гозба је славље), мотивисаног обредом или обичајем, те доменом јела и пића (гозба је објед - ручак или вечера), на основу кога се концепт гозбе метонимијски пресликава на њен искуствено познати темељни домен као што је трпеза и/или софра, што резултира и трансфером имена, па се синонимно са лексемом гозба употребљавају и ти њени метонимијски успостављени домени (гозба је трпеза/софра). Концепт гозбе карактерише и домен количине у оквиру кога се ак-

1 „У оквиру когнитивне лингвистике значење се изједначава са концептуализацијом - образовањем појмова на основу човјековог физичког, чулног, емоционалног и интелектуалног искуства о свијету [...] Апстрактне и сложене појмове не доживљавамо непосредно, већ тако што их конкретизујемо и поједностављујемо, сводимо их на познато искуство“ (Драгићевић 2007: 90). Концептуализација, дакле, обухвата виђење, структурисање и кодирање одређене појаве од стране интерпретатора њеног значења.

2 Термини из когнитивне лингвистике употребљавају се у сљедећим значењима: домен - сегмент знања који се активира у свијести интерпретатора значења неког појма, а који учествује у обликовању значења одређене појмовне структуре и представља основу концептуализације (издвајају се базични или изворни домени, који су елементи физичког искуства и не могу се даље разлагати, као што су нпр. простор, вријеме, звук, тежина, боја, мирис, окус и сл. и апстрактни или циљни домени, као што су живот, љубав, туга и сл. који се на основу поступака концептуалне метафоре или метонимије нпр. пресликавају у изворне, нпр. живот је путовање); фрејм - контекстуални оквир, успостављен на основу искустава и знања о свијету, у коме се разумије значење неког појма, а који сачињава скуп домена; схема - пресликавање конкретних (физичких) искустава о свијету на апстрактне појаве; сценариј - скуп поступака (или очекивања) на основу којих се развија посматрани догађај (в. Лангакер 1987). 
туализује компонента велике количине, па гозба подразумијева обиље јела и пића (гозба је обиље), као и домен квалитета (гозбу чине пробрана јела и пића). Будући да је друштвени догађај, детерминисан обредом или обичајем, на социокултурном плану издвајају се у књижевним текстовима различити конвенционализовани типови гозбе, као што су: епска, манастирска, чорбаџијска, грађанска, сиротињска и сл.; према намјени: гозба за појединачне или групне госте, гозба за војску, а према врсти славља - славске или обредне, те обичајне, као што су: просидба, свадба, праћење на далеки пут итд. У њеној реализацији издвајају се двије друштвене улоге - домаћин и гост, при чему су обје улоге одређене индивидуално или групно. Фрејм гозбе, дакле, утемељен је у циклусу породичног живота и искуствено-прагматички је устаљен. Домени који одређују концепт гозбе развијају наведене базичне метафоре које су искуствено-конвенционалног карактера. Уз њих, у приказивању разних врста гозбе у корпусним књижевним текстовима, успостављају се и иновативне метафоре, засноване на индивидуалном виђењу свијета од стране наратора, чиме настају варијације концепта које представљају културне моделе у оквиру различитих просторно-временских и идеолошко-културолошких оквира књижевне епохе. Ти модели или подмодели представљају посебне сценарије који зависе од реализације примарних и/или секундарних домена у књижевном тексту. Тако се нпр. сценариј гозбе у књижевном тексту обликује на основу домена глади, који се представља начином конзумирања хране и пића од стране госта и као секундарни домен у концепту гозбе представља диференцијалну семантичку компоненту у једном од њених сценарија у коме се гозба уобличава као прекомјерно задовољавање глади и жеђи од стране 
госта лакомог на јело и пиће. Примарни домени обликују гозбу као врсту обједа који се разликује од других, док секундарни својом доминацијом диференцирају стилски маркиране подтипове, који се реализују у књижевном тексту гдје одражавају интенцију аутора да фокусира неки од социокултурних аспеката гозбе као друштвеног догађаја. Концепт традиционалне (сеоске) гозбе посматрамо у приповијеткама српских писаца из периода реализма (П. Кочића, Л. Лазаревића и Б. Станковића) или насталим у духу реалистичке традиције (И. Андрића), будући да је трансформација књижевног текста у умјетнички у том књижевном поступку вјерна или могуће вјерна слика стварности, а тиме и врло блиска појмовно-логичком потенцијалу који природни језик садржи. То омогућује да се аспекти значења концептуално уобличене цјелине, као што је гозба у књижевном тексту, у суштини подударни са неким од рјечничких значења лексема које тај концепт уобличавају, што се у анализи провјерава у одговарајућим рјечницима српског језика.

2. АНАЛИЗА ГРАЂЕ - КАРАКТЕРИСТИКЕ И ФУНКЦИЈЕ ГОЗБЕ У КЮИЖЕВНОМ ТЕКСТУ

У лексикографском одређењу, гозба је „обилан и лепо припремљен обед (ручак или вечера) у част гостију; свечаност, пријем са гошћењем, чашћавањем“ (РМС 2007: 207). Одређена је, дакле, доменима обједа (гозба је ручак или вечера), квантитета (гозба је обилан ручак или вечера), доменом намјене - то није ручак за укућане, него за званице или госте (гозба је посјета), те доменом квалитета који се односи на објед (гозба је лијепо припремљен ручак или част) и на сам 
чин реализације обједа (гозба је свечаност). Наглашеним актуализовањем једног или више њих, сценариј гозбе се у књижевном тексту подтипски раслојава, при чему се у општем концепту гозбе обједињују издвојени подтипови. Тако су домени јела и свечаног обједа, који укључује и домен за гозбу лијепо постављеног стола, основа концептуалне метонимије којом се примарно значење ријечи трпеза (= „сто“) синонимно изједначава са значењем ријечи гозба и у блокираној конструкцији часна трпеза. Синтагма часна трпеза представља „сто у храму, у цркви, иза олтара“ (РМС 2007: 1345), па актуализовањем религијског садржаја који асоцира на обиље вјере и хришћанског поштовања - формира идиоматску основу за заклињање и преклињање:

1) Оче и у Христу брате, тако ти свете причести и часне трпезе, отвори! - преклиње Џибукарда... (Кочић 2005, Мрачајски прото, у: Мрачајски прото, 75)

Часна трпеза евоцира сакрално-жртвени концепт гозбе као јела и пића које се ритуално приноси у славу Бога, па је у датом контексту њена функција амплификативна у експресивном изразу. Придјев часна уз mpпеза кореспондира са глаголом частити или „износити пред некога јело и пиће, приређивати некоме част, гозбу, (у)гостити [...] лепо и обилно јести, гостити се“ (РМС 2007: 1505). Значење овог глагола, конститутивно у концепту гозбе, уз схватање гозбе као обједа или посебно изабраних јела, уводи и домен пића, најчешће вина - које се на гозби усталило ритуално, као религиозна метафора Христове крви ${ }^{3}$, или ракије - такође ри-

3 Обредни предмети који првобитно „служе као материјалне репрезентације божанства у контексту ритуала“у културној традицији настављају да постоје и у „неритуалном контексту“ (в. Лич 1983: 58-59). 
туално-етнографски симболичног пића које код Срба прати животни циклус од рођења до смрти. Приређивати некоме част значи истовремено и одавати некоме част. Тако се у концепту гозбе именица част, као један од њених базичних домена у оквиру кога представља „пиће и јело за госта“" концептуализује и у сценарију који зависи од тачке гледишта, па част можемо апстраховати као „почаст, поштовање које се исказује госту“, односно част је „достојанство домаћина и куће која дочекује госта“. Тиме се успоставља сценариј који одређује однос агенса домаћина и госта тако што гозба исказује, одаје част госту, али истовремено, на тај начин, гозба чува и домаћинову, односно традиционално схваћену домаћинску част. Та част је у систему вриједности високо позиционирана, па се у преклињању и заклињању - који представљају говорне чинове експресивно изнесеног говорниковог захтјева или обавезивања да саговорник или он сам учине оно што је обухваћено садржајем пропозиције на коју се обавезивање односи - апострофира религиозно одређена част као максимално задата мјера и гаранција извршења обавезе.

\section{1. Гозба за госта-намјерника}

Колико је гозба конвенционализована у одређеном друштвеном миљеу, показује сљедећи примјер сеоске гозбе за било кога ко се сматра гостом:

2) На моју вјеру и душу, Ђурђија је жена, једна по једна! Кад сам јој гођ дош'о у кућу - туј ти је нама' кава, па ракија, па цицвара, па кајгана на маслу, па колачићи, п... сто некије' маслајета! Кажем ти, дочека ме боље - боже ме не покарај - него владику! (Кочић 2005, Ђурини записи, у: Мрачајски прото, 35) 
У датом тексту представљен је сценариј уобичајене сеоске гозбе којом се дочекује и части гост-намјерник, што подразумијева такође специјални јеловник који се у сеоској кући Кочићевог времена не служи свакодневно нити се служи укућанима. Тај јеловник показује и која су јела традиционална за одређени крај, па у сиромашно доба крајишког села укључује каву и ракију, којима се гост обавезно дочекује, а потом и јело у коме је намјерно спремљена цицвара (кувано јело од кукурузног брашна, млијека и кајмака), те кајгана на маслу и колачићи. Попис јела показује степен сиромаштва у традиционалној сеоској исхрани - не нађе се у свакој кући у изобиљу масла, јаја и брашна, него се те намирнице чувају за госте. Разноврсност пописа, обједињена синтагмом „сто некије 'маслајета'“, такође наглашава домен обиља и посебности хране - није месна трпеза, али јесте мрсна и масна - што се стилистичким поступком кумулације сабира у архисемској компоненти „масло“, односно „маслајети“ као масна и сласна јела. У изразу је уз то пренаглашена и разноврсност понуде у броју $\mathrm{cmo}$, што и идиоматски значи врло много, јер је то број који када не изражава тачну вриједност нечега, означава „неодређено велику количину нечега, врло много“ (РМC 2007: 1272). Дата гозба фактички има хабитуално-квалификативно значење, тј. гозба је дескриптивног карактера јер се понавља у свим приликама када домаћица дочекује госта („Кад сам јој гођ дош’о у кућу туј ти је нама' кава, па ракија...“). У оквиру ње се потенцира домен дочека госта или „пријема који се некоме спрема при сусрету, посети“, односно идиоматизована синтагма дочекати госта значи „угостити, почастити онога ко је дошао у посету“ (РМС 2007: 316). Гозба, дакле, не реферише на конкретан догађај чашћења, него обиље којим дочекује госта квалификује Ђурђију као 
домаћицу и у традиционално постављеном систему вриједности и позитивних особина жене представља је као „једну по једну“, тј. „изванредну, одличну, најбољу“ (РMC 2007: 503).

Као немаркирана категорија, гост је „особа која је позвана на обед или на свечаност, пријем, званица, узваник“ (РМС 2007: 215), а као маркирана - издваја се „незвани гост“ - непожељан, изненадни, непредвиђени гост, те „високи гост“ - важан или угледан гост (РМС 2007: 215). У дочеку који подразумијева чашћавање госта та два типа нужно се не искључују, него се у пракси реализују у сценаријима „незваног високог или уваженог госта“, „непожељног високог госта“ и сл., што показују сљедећи примјери гозбе за неочекиваног уваженог госта:

3) Стигавши у Љољину полумрачну, непометену и жалосну самачку кућу, фра Марко клону на троножац, који шкрипну и ишчезну под њим. Опружи ноге и спусти руке као човјек који се потпуно предаје умору који га одавно мучи. Извињавајући се по сељачки, Љољо изнесе велику ћасу пуну сурутке, прегршт сира тученика, двије главице лука, и заломи комад кукурузна хљеба. Фра Марко, онако опружених ногу, прихвати длановима ћасу и поче да пије. Пио је дуго и гласно, надимале му се груди, и у тишини се чуло његово тешко дисање и сурутка како цврчи. Пио је тако дуго да је сељак, који је стајао скрштених руку крај огњишта, као у неприлици, погледао час у фратра час преда се. Једва једном отрже фратар ћасу од уста, и хватајући дах, као занесен, даде је Љољи. Дуго је дрхтао и отирао бркове, па онда поче да једе сир, лук и хљеб, слатко и брзо као посленик на гумну. А једнако се презнајао, иако је у кући било студено. (Андрић 1977, Исповијед, у: Жећ), 44) 
Садржај софре - јело и пиће детерминишу социјални статус домаћина - сиромашног сељака, при чему је карактеристично да је домен пића, који на традиционалној српској гозби заузимају вино или ракија, замијењен сурутком. Начин конзумирања хране („слатко и брзо, као посленик на гумну“ - дата слика образује сценариј тежачке глади) и сурутке („сурутка цврчи“ - актуализује појмовну метафору жеђ је ватра) квалификују фратра као натуралистички простог, али друштвено статусног госта који без устезања у свакој хришћанској кући једе као у својој. Понашање сељака, условљено неумјереном и некултивисаном облапорношћу фратра, представља мјеру иманентног му домаћинског поштовања и бојазни да неопрезним покретом не увриједи госта, па он у неприлици погледа час у фратра час преда се. Притом сељак домаћин стоји скрштених руку - он у ствари двори госта. Глагол дворити, који значи „1.а. стајати поред неког (обично за време обеда) спреман на услугу, служити, послуживати госта“" (РМС 2007: 252), укључује у концепт гозбе и домен дворења госта од стране домаћина, који је одређен у оквиру кинезичког кода, као микросистема правила распореда и кретања у простору учесника у одређеном друштвеном догађају. Правила тог кода су врло битна за обредни сценариј као што је нпр. крсна слава. Тиме што га као госта двори, сељак домаћин показује поштовање према свештенику као божијем изасланику.

Тип гозбе предодређује актуализовање појединих домена. Ако је гозба манифестација већ уобичајене посјете одређеног типа гостију - онда подразумијева само обилније јело и пиће. У првом плану је, дакле, домен квантитета. Таква је фратарска гозба за нежељене госте:

4) Чим почне да се пече ракија, учестају турске посјете манастиру. Тај мирис „патоке“ привукао је и Кезму, 
јаничара [...]. У посљедње вријеме с њим је неки Mexмед Биоградлија, јаничар и истински ратник [...]. Тражили су кокош или ћурана, а задовољили су се бравијиме бутом од којег им је Танасије нанизао шиш и испекао на жеравици поред казана. Пошто се најео и напио, Кезмо се повукао у кут и заспао прислоњен уз дирек, са угашеним чибуком поред себе и филџаном у руци. (Андрић 1977, Код казана, y: Жеђ, 58)

Домен квалитета је секундарног значаја, што се рефлектује у односу глагола „тражили су“- „задовољили су се“ и њихових допуна („Тражили су кокош или ћурана, а задовољили су се бравијиме бутом од којег им је Танасије нанизао шиш и испекао на жеравици поред казана“), али концептуализује гозбу емоционалним стањем хедонистичког задовољства госта. И ова као и свака друга гозба одражава у односима домаћина и госта шире друштвене односе. У датом контексту они подразумијевају прећутно прихваћен однос између Турака-насилника и католичког манастира који силом прилика, на изнуђеној гозби, госта кога не уважава дочекује на начин да задовољи његове нагоне за јелом и пићем, а да га притом не испровоцира.

Колико однос домаћин - гост детерминише тип гозбе актуализовањем из домаћиновог угла битног домена који одређује за њега достојну гозбу, показује сљедећи примјер сеоске гозбе за важног госта

5) - Јесте, господине, тај ми је Аркадије пис'о. Вид' како ти знаш! - чуди се Ђуро. Кад је лани пролазио из шера, да 'вође буде учитељ, свратио се мојој кући, па смо цијелу ноћ пили. О, море, господине, Аркадије добро попити! Попили смо читаву пинту (10 ока) ракије. Увијек у мене има ракије. Кажем ти, цијелу ноћ смо пили и чатили - боже ме не покарај - к’о у цркви. 
- Па јесте ли шта јели? - питам ја...

- О, како нијесмо, мој господине? Оборио сам најбоље јање... Било је некако око јација... Нама' ми један запис запис'о; други ми је запис'о у глуво доба, а трећи у зору... а све смо јели, пили и чатили. О, једе добро Аркадије! [...]. Узме комадић меса, чашу ракије, и све штрампа и гледа у мене. О, добро Аркадије, господине, једе, добро пије, и да видиш, добро штрампа. (Кочић 2005, Ђурини записи, у: Мрачајски прото, 33)

Чашћење преваранта Аркадија, који пише по селу записе против урока - социолошки је детерминисан тип гозбе, одређен је сеоским обичајем да се важном госту у какве спада и Аркадије, као „учитељ“ и зналац за тумачење Рожденика и за писање записа од урока, изнесе најбоље јело и пиће које кућа има - да се закоље јагње и точи ракија. У питању је гозба за једног госта која одражава и домен домаћинског одуживања за услуге које гост пружа домаћину и његовој кући. И ова гозба актуализује домен дочека госта. Домаћинска сеоска кућа дочекује госта домаћим производима - јагњећим печењем и ракијом. Наглашавање количине („Попили смо читаву пинту (10 ока) ракије“; „Оборио сам најбоље јање“) иронијског је карактера, јер су и лик и наратор свјесни лакрдијашког карактера Аркадијевих „записа“, па се из тачке гледишта домаћина таква врста гозбе концептуализује као губитак. У базичном домену конкретних значења оборити предмет значи промијенити му положај у простору - са вишег на нижи - што у апстрактном концептуалном домену носи негативну конотацију, будући да је ниже конвенционализовано као непожељније од вищег.

Доменом квантитета, мјереним истом количином цијелим печеним прасетом и 10 ока вина - одређена је 
и гозба за једног госта која репрезентује кесеџијску гозбу, измишљену уз ракијски казан у машти и лагаријама Симеуна ђака:

6) Ј Јадја ата и дадо' да га водају ... Наредио сам био да се ручак спреми, ама кесеџијски ручак: погача на копрен, печен крмак и десет ока вина. Кад се врати', а све оно стоји готово на 'ној равни пред џамијом. Рушим ти ја крметину, пијем вино, а 'оџа једнако учи ... Ту сам 'нако кесеџијски руч'о.. (Кочић 2005, Зулум Симеуна ђака, у: Мрачајски прото, 87)

Гозба за кесеџију или „јунака, доброг борца (који сјече главе противника)“ (Шкаљић 1979: 406), гозба је за Симеуна, који себе у причи представља као насилника и зулумћара који се свети Турцима на Мајдану и захтијева од њих „кесеџијски ручак“ - специјалну „погачу на копрен“, печење - „печеног крмка“, чиме се наглашава домен квалитета, и велику количину вина - „10 ока“ (ока је мјера за тежину и запремину коју су увеле Османлије с 15. на 16. вијек и у запремини износи 1, 330 л). Печени крмак и више од десет литара вина за изнуђену силничку гозбу једном човјеку актуализују домен пренаглашеног квантитета и одражавају представу Симеуна ђака о моћи и епској јуначкој снази - у чему је хипербола традиционално изражајно средство. Избор „крметине“ у односу на јагњетину наглашава такође домен освете према Турцима. Будући да је у исламској вјерској традицији та врста меса забрањена куранским каноном, тај домен је додатно наглашен и аудитивно-просторним контекстом у коме се реализује гозба - Симеун „руши крметину“ истовремено „док 'оџа учи“.

Доменом пренаглашеног квантитета, као и квалитета, детерминисана је и гозба за незваног - непо- 
жељног високог госта кога представља турска војска у крајишком селу. Таква гозба, као и претходна, нужно актуализује у сценарију и домен изнуђене, присилне гозбе у тачки гледишта домаћина, а свечаност уживања у јелу са аспекта госта:

7) Не прођоше ни три мјесеца иза њи'ова пута у Биоград, а из Сарајева дође абер у Ратково: ето Топал-паше из Сарајева, са два табора царског аскера, да потврди ратковску правду и изда нове царске тапије. Спремајте ручак за Топал-пашу и два табора царског аскера!

И Ратково се, дјецо, претвори у голему ашчиницу; коље се, пече се, кува се - није шала на'ранити два табора царске војске! Заклано је шест волова трогодаца и седамдесет овнова и десетеро трзади и преко педесет пилади за везира и његове доглавнике; укувано је двадесет товара јечмена, зобена и кукурузова крува, и десет погача на копрен за Топал-пашу и његове поглавице; испечено је седамдесет и седам тевсија пита, двадесет варићака колачића, три стотине кајгана, три стотине чимбура и три стотине цицвара, - драга су ова јела Турцима - изнијето је на Кадину Воду три стотине карлица варенике, двадесет каца кисела млијека, десет големије' каца сира тученика и два товара масније' сираца, а за везира и његове ћатипе, евендије, муле и 'авизе убијено је десет трмки чела, изнесено тридесет заструга младог скорупа и тридесет здјела варенике под скорупом [...]. Постави се ручак, и царски аскер кад нешто алакну и затуркеса, наклопи се и сладокусно поједе све што је изнијето, пождера, опири све к'о мећава и облиза прсте. (Кочић 2005, Змијање, у: Мрачајски прото, ПК, 172-173)

У примјеру је представљена гозба за незваног, немилог госта, али госта који по сили спада у тзв. „висо- 
ког госта“, који се дочекује огромном количином хране. Гозба је ручак који се поставља турској војсци и то у количини која показује и да село није сиромашно и да је турска војска као гост незасита гомила сладокусаца којима је осим разних врста меса, хљеба, погача, цицвара, кајгана, сирева, кајмака, слатког и киселог млијека служен и мед са младим скорупом, због чега је „убијено десет трмки чела“. Попис свих јела која се катафорично супсумирају у хиперониму храна, заступљеном на почетку набрајања његових разноврсних хипонима (у глаголу нахранити - „није шала на'ранити два табора царске војске“), укључује и попис активности које претходе изнуђеном ручку за војску и показују да је такав ручак наметнута обавеза групном домаћину, читавом селу, чиме се развија концепт гозбе као жртве коју трпи домаћин. Будући да је домаћин трпилац насиља, све радње су представљене пасивним конструкцијама које уопштавају („коље се, пече се, кува се“) или имперсонализују конкретног вршиоца („заклано је“, „укувано је“, „испечено је“, „изнијето је“, „убијено је“, „постави се"). Тиме се наглашава сам ручак и његов богати садржај - у форми субјекта пацијенса, семантичког носиоца партитивне синтагме са главним бројем који прецизира огромну количину („шест волова трогодаца и седамдесет овнова и десетеро трзади и преко педесет пилади“; „седамдесет и седам тевсија пита, двадесет варићака колачића, три стотине кајгана, три стотине чимбура и три стотине цицвара“; „три стотине карлица варенике, двадесет каца кисела млијека, десет големије' каца сира тученика и два товара масније’ сираца“; „десет трмки чела, изнесено тридесет заструга младог скорупа и тридесет здјела варенике под скорупом“). У сиромашном друштву ова гозба је пустошење српског домаћинског села од стране вишевјековног зулумћара, 
Турака-изјелица. Однос домаћина према гостима који представљају турску војску, везира, пашу и њихове „поглавице“ показује се начином како је представљен сам ручак. Та слика је дата такође у пасивно-обезличеној форми јер подразумијева уопштено-колективног вршиоца - изјелицу („постави се ручак“; „наклопи се и сладокусно поједе све“; „пождера, опири, облиза прсте“). Глаголи који приказују сам начин обједовања експресивне су семантике и дочаравају предимензионирану брзину у обједовању и обликују сценариј госта, који карактеришу домени: гост је метафорично представљен као физичка сила („наклопи се“ = навалише, брзо почеше јести, „опири“ = пометоше, поједоше без остатка); гост је крволочна животиња, јер контекст осликава његову животињску незајажљивост („пождера се" = поједоше као животиње); гост је сладострасник, јер допуне и одредбе прецизирају хедонистички однос Турака према јелу („сладокусно поједе све“; „облиза прсте“).

\section{2. Обредно-обичајна гозба}

Промјена стауса у нечијем животу - рођење, крштење, вјенчање и сл. у концептуалном смислу „представља тренутни прелаз из једне категорије у другу“, из једног друштвеног статуса у други, а такав „прелазак изискује ритуал, прекорачење друштвених граница које се догађа“" (Лич 1983: 53) у одређеном контексту, на основу устаљеног модела, тако што „учесници ритуала имају заједнички комуникацијски доживљај путем мноштва различитих чулних канала истовремено; они одигравају сређен низ метафоричких догађаја у границама територијалног простора који је и сам сређен да би обезбедио метафорички контекст за одигравање. 
Вербална, музичка, кореографска и визуелно-естетска 'димензија', све оне одреда, могу да образују компоненте целокупне поруке. Када учествујемо у таквом ритуалу, ми региструјемо све те поруке у исто време и кондензујемо их у јединствен доживљај који описујемо као 'учествовање на свадби' или 'учествовање у сахрани'“ (Лич 1983: 64). Неки од тих друштвених догађаја обичајног су карактера и подлијежу мањем степену кодираности улога у оквиру ритуала, него што то намеће обиљежавање традиционалних обреда, па је гозба - одређена доменима обједа, лијепо спремљеног јела и пића, чашћења и прославе - фактички једино заједничко обиљежје у њиховој реализацији. У такве обичајне гозбе спада и праћење на далеки пут члана домаћинства - у војску, на школовање и сл. Уз остале, већ наведене домене, у књижевном тексту често се наглашава и домен припрема јела за послужење гостију:

8) И после месец дана већ се опрема дијете на пут. Силне се припреме чине.

Дан пред полазак мутљају се жене из цијелог села по поповој кући. Ту је камара сирчева, колача од пекмеза и тијеста, лепиња и погача, лонаца с кајмаком, живих и пржених пилића, пастрме и толико „заире“ да би Војин четовођа рахат цијелу чету њоме нахранио. (Лазаревић 2005, Школска икона, у: Швабица, 87)

Припреме се персонификују као жива сила, а количина хране која се служи на гозби, поводом одласка попове кћерке Маре на школе, изражава се лексемом „камара“ (или „гомила, хрпа нагомиланих предмета“ РМС 2007: 518) и пореди са количином која је потребна да се нахрани чета војника. Њена разноврсност експлицирана у координираној синтагми лексема којима се 
набрајају разна јела сумарно се подводе под заједничку архисему, под хипероним представљен оријентализмом заира, чије је значење „храна“ (Шкаљић 1979: 644), па је кумулацијско-дистрибуцијско нагомилавање и овдје основни стилски поступак (в. Ковачевић 2000: 145-157) осликавања гозбене трпезе.

У обичајну гозбу убраја се и просидба:

9) Течи Тодору као да не би баш по вољи ова погодба. Он се намршти и одби руком: - То је ваша ствар! ...Како се вас двоје наредите. ...

Она изађе. Одмах донесоше вино и свакојаке мезе. Убрзо Стојан Приклапало поче наздрављати. Друштво се развесели. С авлије чу се гајдаш и топот ногу по такту. У кухињи Вучко, међ' девојкама, натерао фес на око, и шаркијаш иза њега бије по жицама и одсеца:

Ту-ни ја-на, ту ногом, Ето праха под ногом!

И у соби Цигани развалише вилице и полегоше по ћеменетима. Бубањ у мозак пробија! Вино ко гром! (Лазаревић 2005, Он зна све!, у: Швабица, 195-196)

Прослава просидбе праћена је музиком и пјесмом. Сама трпеза представљена је вином и свакојаком мезом (мезе = „млечни и сухомеснати производи, салата и др. јестиво које се помало узима уз пиће, као предјело или у другим приликама“ РМС 2007: 694) - и једно и друго дато је у форми ближег објекта уз глагол „унесоше“, чија је семантика „служење хране и пића“, с тим да је „свакојаке мезе“ у облику партитивног генитива, којим се иначе изражава неодређена количина, а придјевском замјеницом „свакојаке“ и разноврсност. Будући да је просидба по природи ствари договор са неизвијесним исходом, гозбено јело је једноставније („мезе“) и не подразумијева посебне припреме као што су кување 
чорби и печење меса. Ова гозба је представљена лапидарно - трпеза је осликана само са два-три језичка елемента, а тежиште је на наздрављању („Убрзо Стојан Приклапало поче наздрављати“) и весељу које није везано за храну, него за вино. Наздрављање је ритуал у коме домаћин или један од гостију изражавају жеље „за добро здравље, срећу, успех и сл. испијајући при томе неко (алкохолно) пиће“ (РМС 2007: 767). У интензивираној слици весеља као музике, пјесме и игре понавља се значај и снага вина које опија и развесељава. „Вино ко гром!“- наглашава се узвичном реченицом, чиме се, у ствари, слави снага и значај тог најзначајнијег гозбеног пића на обредним и обичајним прославама и, поређењем са громом, концептуализује као природно моћна сила.

Свадбена гозба нужно укључује разна јела, месо и вино, чак и када је, из неких разлога, уприличена као „скромна“:

10) Венчали су се. Свадба је била скромна, према мужу удовцу, као свака удовичка свадба [...]. Била је игра, чак и „шарено оро“ [...]. Само што није било вечере, па као што је обичај да се после целе ноћи седи, пије, а сутра испраћа старојко, кум... већ је био ручак, а на њему њена и његова породица. И старији седели су за софром, млађи играли у дворишту са осталим светом. [...]. Ашчика, засукана, с голим лактовима, гурала се, готовила тамо у кујини; иза околних зидова вириле су жене, девојке и гледале овамо [...]. По столу исполивано вино, изглодане кости, растрен дуван ... свуда јак мирис од јела и проливена пића. (Станковић 2005, Покојникова жена, у: Стари дани, 135-137)

У опису свадбе назначени су обичаји од којих се дјелимично одступа зато што је младожења удовац („није 
било вечере, па као што је обичај да се после целе ноћи седи, пије, а сутра испраћа старојко, кум“), али весеље - игра и пјесма - представља неизостављив домен њене концептуализације. Гозба је осликана уопштено - поступком металепсе ${ }^{4}$ и синегдохе ${ }^{5}$ назначене су велике количине јела које подразумијева месо („изглодане кости“), велике количине вина („испроливано вино“) и других масних јела - у мирисима који се шире по кући („свуда јак мирис од јела и проливена пића“). Тиме се сугерише обиље и квалитативна разноликост јела. Та два домена (квантитет и квалитет) наглашени су и начином спремања или „готовљења“ јела („Ашчика, засукана, с голим лактовима, гурала се, готовила тамо у кујини“), за шта је задужена „ашчика“ или кухарица (Шкаљић 1979: 102), чиме се показује да је свадбена гозба увијек посебно лијепо спремљен објед, и то од стране у том поспу умјешне особе.

Обредна гозба, као што је прослава Божића, актуализује домен радости прослављања и честитања од стране драгих гостију:

11) Полица се цакли саханима [...]. Око огњишта кркћу лонци, а под вршњиком цврчи печење. Улазим у собу. Мајка ме тобож не види ... Пружам јој нафору и питам: да ли је ко долазио? [...]. И брзо ми износи делове осушеног врапца, да од њега прво окусим, како бих целе године био лак, као што је врабац. Онда остало. Једем [...]. Кандило пуцкара. Тамјан се вије и шири полако, таласасто. Из кујне миришу јела ... она поставила софру, метнула хлеб, со, запаљену свећу на средини и онда остало; донела у

4 Металепса - „фигура у којој се једно стање или једна ситуација види као посљедица неког далеког узрока“ (Лешић 2005: 286).

5 Синегдоха - „стилска фигура код које се лексемом која означава дио именује цјелина, или обрнуто“ (Ковачевић 2000: 61). 
саханчићу јела из кујне, да се не би после морала дизати за време ручка. [...]. Соба се испуни масним, јаким мирисом јела ... а она шапуће:

- Господе, Христе, Свети Никола, чудотворче, славо моја! Погледај, Господе, смилуј се и помози. Благослови софру, хлеб твој, што га ти даде .... Ја јој, држећи чашу ракије на длану, онда прилазим руци, и, нудећи у исто време свој образ, честитам празник:

- Христос се роди, нано, и срећан дан!

-Ваистину и с тобом, а до године да Бог да да ми ти ... - и загрцну се, те једва испи чашу...

... На сандуку, у старом послужавнику стоје поређане чаше, до њих велика чепрња вина [...] све је било спремљено. Али узалуд кад никог нема да га угостимо и дочекамо. Што је долазило, то је дошло изјутра, на ракију, као да нас штеде, јер знају да немамо [...]. Зато, ваљда, мајци игра тежак осмех, и очи је почеле да сврбе гледајући кроз капију на улицу, по којој свет врви, промиче испред наше отворене капије, а нико у њу не улази, те нам двориште и кућа пусти и тужни [...]. На нашој капији уђе заносећи се, са заваљеном шубаром, наш ч'а Јован, ортак и побратим покојног оца, а за њим, тискајући се, свирачи [...]. За мајку не знам како је изашла преда њ у кујну, само знам да мени срце стаде ... И Цигани засвирају. Запишти зурла, па мислим да се чује чак у Турско. Бубањ бије, стакло игра у ћерчивима, кандило прска и с греде, озго, пада црвоточина [...]. А мајка, са сузом која јој полако, полако мили низ образ, гледа ме где гологлав стојим између њих и свирача и дворим их са очевим сахатом на прсима, па као да вели: - Божић, сине. Видиш ли? (Станковић 2005, Наш Божић, у: Стари дани, 77-82).

Дати примјер показује колико је обред прослављања Христовог рођења, као најрадоснијег хришћанског празника, истовремено везан за уски породични круг, али и уклопљен у шири друштвени контекст у коме се 
одређује социјални статус домаћина и куће. Ни слика богатом трпезом превладаног сиромаштва („Око огњишта кркћу лонци, а под вршњиком цврчи печење“; „Соба се испуни масним, јаким мирисом јела“), ни породична хармонија у којој мајка и син-насљедник, који прерано, али одговорно преузима улогу домаћина („Ја joj, држећи чашу ракије на длану, онда прилазим руци, и, нудећи у исто време свој образ, честитам празник“; „гологлав стојим између њих и свирача и дворим их са очевим сахатом на прсима") проводе све што традиционални обред подразумијева („Пружам јој нафору“; „брзо ми износи делове осушеног врапца, да од њега прво окусим, како бих целе године био лак, као што је врабац“; „она поставила софру, метнула хлеб, со, запаљену свећу на средини и онда остало“; „држећи чашу ракије на длану, онда прилазим руци, и, нудећи у исто време свој образ, честитам празник“) - не могу да надомијесте искљученост из друштва („никог нема да га угостимо и дочекамо“; „мајци игра тежак осмех, и очи је почеле да сврбе гледајући кроз капију на улицу, по којој свет врви, промиче испред наше отворене капије, а нико у њу не улази, те нам двориште и кућа пусти и тужни“). Прихваћеност у друштву и дијељење божићне радости са гостима - услов су за осјећај личног достојанства и духовног благостања („На нашој капији уђе заносећи се, са заваљеном шубаром, наш ч’а Јован, ортак и побратим покојног оца, а за њим, тискајући се, свирачи ... За мајку не знам како је изашла преда њ у кујну, само знам да мени срце стаде ... И Цигани засвиpajy [...]. А мајка, са сузом која јој полако, полако мили низ образ, гледа ме где гологлав стојим између њих и свирача и дворим их са очевим сахатом на прсима, па као да вели: - Божић, сине. Видиш ли?), па се божићна гозба, као породична прослава, уз наглашен домен до- 
маћина - (нај)старијег мушкарца у кући и дворења гостију, потврђује доменом посјете, односно радошћу дијељењем славља са гостима.

Обредна гозба - крсна слава актуализује бројност гостију - званица, њихов распоред за столом и обред са симболиком славских свијећа, славског колача и вина:

12) Софра пружена од краја на крај собе. Старији у чело, до њих старке, и тако редом, чак до краја, где су млађе жене, али оне ретко седе, већ су у дечјој соби где умирују и успављују малу децу, или у кујни и тамо помажу тетки. А софра је застрта чаршафом, у челу је велики колач, на њему три као крст воштане свеће, чаша вина, а ниже њега по софри, наниже, поређани цели хлебови, око њих чанци јабука, крушака, ораја и грожђа „из туршије“ [...]. Теча стоји гологлав. Послужује. Гости чисти, обријани, преко колена пребачен им убрус за руке. Беле им се њихове нове кошуље, миришу им „стајаће“ хаљине на суве дуње из сандука [...]. Дође и поп. Сви стоје гологлави, он чита, кади, они метанишу, крсте се. Пресече се колач и онда настаје слава. Почну здравице. Чорба се по три пута поједе. Жене сав хлеб пред собом поједу, штрцкајући, поједу и засуте се чекајући док дође здравица „за слатку вечеру“ и онда вечера. Дође и она. Вечерамо. Чује се како кашике звече и пуцају вилице. Пред сваким „сатлик“ вина. Чим се начне, одмах се допуњује [...]. Вечера је при крају. Почеше опет здравице. Софра већ мокра од вина, умрљана од јела и пуна костију. (Станковић 2005, Стари дани, у: Стари дани, 88-91)

Слава укључује обред и обичај служења хране прије вечере („по софри, наниже, поређани цели хлебови, око њих чанци јабука, крушака, ораја и грожђа 'из туршије'“) и оне која се служи након ломљења славског колача. Концептуализовање просторне метафоре огледа 
се у истом принципу по коме су распоређени и гости за столом и главна јела и предјела - „у чело“ главна јела и главни гости, а „ниже“ споредни („старији у чело, до њих старке, и тако редом, чак до краја, где су млађе жене“; „софра је застрта чаршафом, у челу је велики колач, на њему три као крст воштане свеће, чаша вина, а ниже њега по софри, наниже, поређани цели хлебови, око њих чанци јабука, крушака, ораја и грожђа 'из туршије“). Доминантна је и улогу домаћина - који гологлав служи - двори госте („Теча стоји гологлав. Послужује“). Карактеришу је велике количине вина, разних јела, чорбе, месо обавезно - обиље јела и пића које претходи самој вечери као главном славском јелу, а посебно је наглашено у оквиру ње - гости, весели, ишчекују њену сласт („здравице 'за слатку вечеру““) и вечерају обилно. Количина хране која се служи и једе директно је наглашена итеративношћу поступка служења јела: „чорба се по три пута поједе“ или метонимијски: „кашике звече и пуцају вилице“, чиме се концептуализује начин на који званице једу као природна непогода („звече“, „пуцају“). Славске гозбе подразумијевају домен свечаности - што показује изглед гостију и домаћина, пригодно одјевених и дотјераних („Гости чисти, обријани, преко колена пребачен им убрус за руке. Беле им се њихове нове кошуље, миришу им 'стајаће' хаљине на суве дуње из сандука“). Врло је наглашен домен прославе као весеља - радост и достојанство улазе у кућу са гостима и изражени су у аудитивној слици у којој доминира весели жамор старијих, младих жена, мале дјеце. Радује се, једе и пије и наздравља - у славу бога и благостања породице, па се с тим циљем славска трпеза или софра концептуализује као приношење жртве, што је назначено у металепсично-метафоричној слици „софра већ мокра од вина, умрљана од јела и пуна костију“. 
Обредна гозба се не односи само на прославе, него обухвата и даће или подушја, синонимне лексеме које према рјечничкој дефиницији значе да је у питању „обредна гозба за успомену на покојника“, односно „храна и пиће који се служе на подушној гозби и остављају на гробу после погреба или помена“ (РМС 2007: 955, 246):

13) И ако не сваког дана а оно сваке суботе и уочи празника, испочетка с мајком, а после, кад јој дете порасло и ојачало, с дететом је излазила на гроб и клечала. Тада би на гробу увек била разгрнута бошча с тепсијом, у којој је било понуда: пите, јабуке, грожђе и кришке печене бундеве (све оно што је он радо jeо). Бошча би се белела, одударала од трошне, црне земље гроба... (Станковић 2005, Покојникова жена, у: Стари дани, 124)

14) Мита насред собе. Испружен, мртав. Већ и покров пребачен преко њега [...]. До главе му седела је мати и укочено, немо гладила му је и исправљала праменове његове косе по челу, испод феса. Више главе му, у чинији пуној брашна, горела је једна велика свећа, са још пуно око ње малих свећа запаљених од оних што су дошли [...]. Око њега, до прозора, по миндерлуцима били су поређани мушки, а доле, до врата, за дугачком софром, биле су жене, које су још вечерале [...]. Седосмо међу остале. Сви ћуте. Нико не говори. Чак у мртвог Миту и не гледају. Људи, прејели, мешкоље се, отпасују се и намештају. Жене још вечерају. Једу обично много и ужурбано. А више главе Митине гори она велика свећа, осветљава целу собу треперећи [...]. А иначе ништа није било чега сам се ја толико плашио. Ни запевка, ни нарицања. Жене су јеле, мушки пушили и ћутали. (Станковић 2005, Они, у: Стари дани, 119-121) 
И ова два типа задушне софре актуализују домен обиља хране. У првом примјеру представљено је изношење понуда које је покојник волио да једе, суботом на његов гроб: „пите, јабуке, грожђе и кришке печене бундеве (све оно што је он радо јео)“. Покојник се тиме концептуализује као гост коме се износе специјална јела као понуде. Списак хране се не исцрпљује наведеним врстама, него се сумира и проширује у уопштеном додатку у парентези („све оно што је он радо јео“). Том зависном реченицом рестриктивно је одређена архисема у хиперониму храна, а хипоними су сведени на онај избор јела која су пријала покојнику за живота. Изношењем јела и пића и гошћењем у част покојника симболично се продужава његова егзистенција - у сјећању на овом и у задушном животу на оном свијету. Базичним доменом боје - контрастом бијеле боје „бошче“ и црне боје земље на гробу - концептуализује се однос између овог и оног свијета, између живота и смрти као контраст свјетла и таме. У другом примјеру је даћа која се служи уз покојника у кући - не наводи се њен садржај, али се наглашава трајање самог јела непосредно: „Жене још вечерају. Једу обично много и ужурбано [...] Жене су јеле...", или кроз реакције на његово обилно конзумирање: „Људи, прејели, мешкоље се, отпасују се и намештају“. Задушне гозбе такође одређује и домен свечаности којом се исказује достојанство покојнику и част - етичност, емоционалност и оданост укућана који приређују даћу. Та врста свечаности искључује домен славља, али природа гозбе не искључује домен уживања у јелу од стране гостију. Будући да је однос домаћина и гостију, који својим присуством указују почаст покојнику и ожалошћеној породици, емоционално различито детерминисан, односно да емоционална неангажованост госта одређује и његову равнодушност у 
схватању смрти као уобичајеног животног догађаја, не ремети се ни њихова улога која је у оквиру свих варијаната гозбеног обједа хедонистички одређена.

\section{2. ЗАКЉУЧАК}

Концептуално сажимање обухвата све варијанте реализације традиционалне гозбе у српској реалистичкој или у књижевности насталој на реалистичком насљеђу. Као и свака појава која је структурално сложена као конвенционализовано одређен догађај, и гозба је утемељена на базичним доменима које представљају: обилан свечани објед (ручак или вечера), који домаћин, различитим поводима, организује за госта. На основу тих домена концептуализује се традиционална гозба актуализовањем апстрактних циљних домена, који се издвајају као примарни - заступљени у оквиру реализације гозбе као традиционалног друштвеног догађаја, те као секундарни - контекстуално условљени у оквиру одступања од примарног модела. Њихов однос - присуство и/или одсуство или степен наглашености појединих домена - у основи је типолошке диференцијације подмодела, који се издвајају на основу доминације или елиминације појединих од њих, што наводимо у прегледу који слиједи.

1. Гозбени објед, временски детерминисан као ручак или вечера, као најбитнији, карактеришу базични домени: посјете (ручак за госта), свечаности и обиља хране и пића, лијепо спремљеног и постављеног.

2. Његови примарни циљни домени развијају се из базичних:

а) Домен посјете издваја гозбу за различите врсте гостију: намјерника и званицу, па се издвајају и примарни типови гозбе: за незваног уваженог госта (нпр. 
6р. 3, гозба за фратра; 6р. 5, гозба за Аркадија) и за незваног неуваженог госта (нпр. бр. 4, гозба за Турке код манастирског ракијског казана); обредно-обичајна гозба за званице (праћење укућанина на далеки пут, просидба, свадба, крсна слава, прослава религиозних празника; подушне гозбе). Улоге домаћина и госта укључују домен њиховог односа који детерминише одавање вишег или мањег степена почасти госту од стране домаћина, што се манифестује у степену његове срдачности и предусретљивости, па домаћин према госту може бити ,један по један“ (нпр. бр. 2, Ђурђијино чашћавање госта-намјерника), снисходљив (нпр. бр. 3, Љољо према фратру), формално љубазан (нпр. бр. 4, Танасије код манастирског казана), интересно љубазан (нпр. бр. 5, Аркадијев домаћин), свесрдно предусретљив (нпр. бр. 11 , син и мајка на божићној гозби), може да изражава достојанство и поштовање (нпр. бр. 12, теча гологлав стоји и послужује госте на слави) и сл.

б) Домен свечаног обједа у циљним доменима се градуализује кроз односе домаћина и госта: гозба за госта намјерника свечанија је од ручка за укућане, тј. свечаност је минималног карактера и актуализује циљни домен дочека као чашћења госта од стране домаћина $(6$ p. $3,4,5)$; гозба за званице максимализује степен свечаности и актуализује домен дворења госта од стране домаћина као чин изузетног поштовања (6р. 3,11 , 12). Базични у људском мишљењу домени времена и простора, изражени кроз бинарни однос прије - послије, напријед - назад, горе - доље концептуализују се у циљним доменима распореда гостију за столом, као и распореда јела на столу, посебно на гозбама обреднообичајног карактера (бр. 11, 12). Напријед или „у чело“ стола постављају се важнији гости и главна јела, а ниже споредни гости и предјела или мезе. 
в) Домен обиља јела и пића манифестује се у пробраности јела и пића, као и у великим количинама и једног и другог, чиме се апстрахује домен квалитета и квантитета гозбе: квалитет је изражен синонимним

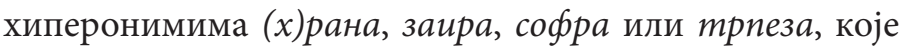
карактерише, као најдоминантнија, компонента мрса масне хране животињског поријекла (меса и млијечних производа, јаја и сл.), те њиховим бројним хипонимима, заступљеним у традиционалној и регионалној исхрани, док је пиће алкохолног карактера - вино и/или ракија и кафа. У оквиру циљних домена које разноврсност софре развија јесте и домен припреме (клање животиња, печење, кување, спремање, постављање итд., нпр. бр. 7) који метафорично-метонимијски концептуализује кућу која спрема гозбу као ашчиницу, чиме се отвара и улога ащчике или куварице, индивидуално или групно одређена (жене у селу, млађе жене и сл., бр. 7, 8, 9, 11, $12)$, као и домен који се односи на начин конзумирања јела од стране гостију - слатко, неизмјерено много, халапљиво, чиме се гост концептуализује као сладокусац (нпр. бр. 4, 5, 10, 12, 14), хедониста или сладострасник (нпр. бр. 6, 7), халапљив (бр. 3) и сл.

3) Секундарни домени усложњавају концепт гозбе одступањима од традиционалног кода у експресивном смислу, наглашавањем неког од домена и његовим метафорично-метонимијским концептуализовањем. Тако се у оквиру секундарних домена успостављају сљедеће релације у концепту гозбе:

a) Уколико је помјерањем традиционалног оквира захваћен домен посјете који се односи на улогу госта као намјерника или званице, концептуализује се изнуђена гозба за госта насилника (нпр. 6р. 7, гозба за турску војску; бр. 6, кесеџијска гозба за Симеуна ђака). Гост се пренаглашавањем начина конзумирања хране 
као прождрљивости метафорично представља као физичка сила, као крволочна животиња (нпр. бр. 7, гозба за турску војску) или као осветник (нпр. бр. 6, Сименуова кесеџијска гозба).

б) Домен свечаности може да се обликује као весеље, па је гозба концептуализована као прослава, какве су обредно-обичајне славске гозбе, свадбене, испраћајне и сл. Када се тај аспект неутралише - у питању је гозба у сврху дочека и чашћења госта-намјерника, док супротно маркирано расположење жалости детерминише подушја као гозбе у помен мртвих. Славља (нпр. бр. $8,9,10,11)$ и подушје (нпр. бр. 13,14 ) концептуализују метафору обредног приношења жртве, јер се у оквиру гозбе наглашава значај вина као метафоре Христове крви и јестива (хљеба, меса) - као метафоре Христовог тијела. Уз то се - секундарно - у функцији славског расположења вино (или ракија) концептуализује као природно моћна сила (нпр. бр. 9).

в) Нијансирања у оквиру реализације домена обиља којима се наглашава количина конзумирања хране, концептуализују се метафором у којој се глад и жеђ схватају као природне силе (нпр. бр. 3, жеђ је ватра која се гаси сурутком на гозби коју сиромашни Љољо поставља фратру) или метонимијски (нпр. бр. 12, „пуцају вилице“, „звече кашике“ на славској гозби) или метонимијско-металепсички наглашеним дјеловима цјелине који су у ствари остаци поједене хране и попијеног пића, односно посљедице прекомјерно поједене количине хране (нпр. бр. 11, „по столу испроливано вино, изглодане кости“ на свадбеној гозби). 


\section{Извори}

Андрић 1977: Andrić, Ivo. Žeđ. Sarajevo-Zagreb: Svjetlost-Mladost, 1977.

Кочић 2005: Кочић, Петар. Мрачајски прото. Београд: Политика - Народна књига, 2005.

Лазаревић 2005: Лазаревић, Лаза. Швабица. Београд: Политика - Народна књига, 2005.

Станковић 2005: Станковић, Борисав. Стари дани. Београд: Политика - Народна књига, 2005.

\section{Литература}

Драгићевић 2007: Драгићевић, Рајна. Лексикологија српског језика. Београд: завод за уџбенике, 2007.

Ковачевић 2000: Ковачевић, Милош. Стилистика u граматика стилских фигура. Крагујевац: Кантакузин, 2000.

Кончаревић 2015: Кончаревић, Ксенија. Поглед $у$ теолингвистику. Београд: Јасен, 2015.

Лангакер 1987: Langacker, R. W. Foundations of Cognitive Grammar, Theoretical Prerequisites, Vol. 1. Stanford, California: Stanford University Press, 1987.

Лешић 2005: Lešić, Zdenko. Teorija književnosti. Sarajevo: Sarajevo Publishing, 2005.

Лич 1983: Лич, Едмунд. Култура и комуникација. Београд: Просвета, 1983.

РМС 2007: Речник српскога језика. Нови Сад: Матица српска, 2007.

Шкаљић 1979: Škaljić, Abdulah. Turcizmi u srpskohrvatskom jeziku. Sarajevo: Svjetlost, 1979. 
Milanka Babić

\section{THE CONCEPT OF TRADICIONAL FEAST IN SERBIAN LITERATURE}

In conceptual-cognitive analysis feast (Serb. gozba) is a social event that belongs to the domain of celebration ("feast is celebration"), which is motivated by the ritual or the custom, as well as the domain of food and beverages ("feast is a meal - a lunch or a dinner"), on the basis of which the domain of feast reflects itself via metonymy onto its base domain which is dining table (Serb. trpeza and/or sofra), and to which it is experientially related. This also results in the transfer of names- those domains that are related via metonymy are used as the synonyms of the lexeme feast ("feast is a meal table"/ Serb. "gozba je trpeza/sofra"). The concept of feastis also characterized by the domain of quantity which in itself implies big quantities of certain substance, therefore feast (Serb.gozba) itself implies the abundance of food and beverages ("feast is abundance"/ Serb. "gozba je obilje"). Since the feast is a social event, determined by a ritual or custom, in relation to the socio-cultural background different conventionalized types of feast can be found in literary texts such as: epic, monastery, janissary officers', civic, peasant, etc., there are also those based on the purpose: feast for guests, feastfor army, or according to the type of the feast - or those organized for "slava" or certain rituals, and finally those related to various customs, such as: marriage proposal, wedding, seeing someone off to a long trip. In the realization of the feast two social roles can be singled out - the host, the one who is celebrating or the one who organizes it (the agens), and the guest - the one whose role is more or less static, and both of these roles can be performed individually or by a group. The domains that determine the concept of feast develop the basic metaphors that are of experiential and conventional character. Together with these, for the purpose of illustration of different types of feasts, innovative metaphors are being created based on the narrator's individual view of the world, which results in various concepts that represent cultural models within different special and temporal, as well as ideological and cultural background of the literary epoch. 